\title{
Preferences over Inflation and Unemployment: Evidence from Surveys of Happiness
}

\section{Citation}

Di Tella, Rafael, Robert J MacCulloch, and Andrew J Oswald. 2001. “Preferences over Inflation and Unemployment: Evidence from Surveys of Happiness." American Economic Review 91 (1): 335-41. https://doi.org/10.1257/aer.91.1.335.

\section{Permanent link}

http://nrs.harvard.edu/urn-3:HUL.InstRepos:41426668

\section{Terms of Use}

This article was downloaded from Harvard University's DASH repository, and is made available under the terms and conditions applicable to Other Posted Material, as set forth at http:// nrs.harvard.edu/urn-3:HUL.InstRepos:dash.current.terms-of-use\#LAA

\section{Share Your Story}

The Harvard community has made this article openly available.

Please share how this access benefits you. Submit a story.

Accessibility 


\section{Preferences over Inflation and Unemployment: Evidence from Surveys of Happiness ${ }^{1}$}

\author{
Rafael Di Tella \\ Harvard Business School
}

\author{
Robert J. MacCulloch \\ ZEI, University of Bonn
}

and

Andrew J. Oswald

University of Warwick

Revised October 5, 1999.

Modern macroeconomics textbooks rest upon the assumption of a social welfare function defined on inflation, $\pi$, and unemployment, $U{ }^{2}$ Yet no formal evidence for the existence of such a function has been presented in the literature. ${ }^{3}$ Although an optimal policy rule cannot be chosen unless the parameters of the presumed $\mathrm{W}(\pi, \mathrm{U})$ function are known, that has not prevented its use in a large theoretical literature in macroeconomics.

This paper has two aims. The first is to show that citizens care about these two variables, namely, that inflation and unemployment belong in a well-being function. The second is to calculate the costs of inflation in terms of unemployment -- in other words to try to measure the relative size of the weights attached to these variables in social wellbeing. Policy implications emerge.

\footnotetext{
${ }^{1}$ Corresponding author: Rafael Di Tella, Morgan Hall, Soldiers Field, Boston, MA 02163, USA. For helpful discussions, we thank George Akerlof, Danny Blanchflower, Andrew Clark, Ben Friedman, Duncan Gallie, Sebastian Galiani, Ed Glaeser, Berndt Hayo, Daniel Kahneman, Guillermo Mondino, Steve Nickell, Julio Rotemberg, Hyun Shin, John Whalley, three referees, and seminar participants at Oxford, Harvard Business School, and the NBER Behavioral Macro Conference in 1998. The third author is grateful to the Leverhulme Trust for research support.

${ }^{2}$ See, for example, Olivier Blanchard and Stanley Fischer (1989), Michael Burda and Charles Wyplosz (1993) and Robert Hall and John Taylor (1993). Early influential papers include Robert Barro and David Gordon (1983).

${ }^{3}$ Gregory Mankiw [1997] describes the question "How costly is inflation?" as one of the four major unsolved problems of macroeconomics.
} 
Economists have often puzzled over the costs of inflation. Survey evidence presented in Robert Shiller (1996) shows that, when asked how they feel about inflation, individuals report a number of unconventional costs, like exploitation, national prestige and loss of morale. Yet skeptics wonder. One textbook concludes: "we shall see that standard characterisations of the policy-maker's objective function put more weight on the costs of inflation than is suggested by our understanding of the effects of inflation; in doing so, they probably reflect political realities and the heavy political costs of high inflation." (pp. 567-8, Blanchard and Fischer (1987)). Since reducing inflation is often costly, in terms of extra unemployment, some observers have argued that the industrial democracies' concern with nominal price stability is excessive -- and have urged different monetary policies. ${ }^{4}$

This paper proposes a new approach. It uses subjective data collected from random samples of individuals. These data cover many countries and provide selfreported measures of how happy and satisfied individual respondents are with their lives. We then correlate happiness data with inflation and unemployment in what could be called "well-being" functions to study these questions. Only a few economists have looked at patterns in reported well-being. Richard Easterlin (1974) helped to begin the literature. Later contributions include Yew-Kwang Ng (1996), Robert Frank (1985), Ronald Inglehart (1990), Andrew Oswald (1997), and David Morawetz et al (1977). More recently $\mathrm{Ng}$ (1997) discusses the measurability of happiness, and Daniel Kahneman, Peter Wakker and Rakesh Sarin (1997) provide an axiomatic defence of experienced utility, and propose applications to economics. Our paper also borders on

\footnotetext{
${ }^{4}$ A recent contribution to this debate in the U.S. is Paul Krugman's piece "Stable Prices and Fast Growth: Just Say No", The Economist, August 31 ${ }^{\text {st }}, 1996$.
} 
work in the psychology literature; see for example Edward Diener (1984), David Myers (1993), and William Pavot (1991).

Section I describes the main data source, the Euro-Barometer Survey Series. Partly the creation of Ronald Inglehart at the University of Michigan, this records happiness and life satisfaction information on 264,710 people living in twelve European countries over the period 1975 to 1991 . We also examine the United States General Social Survey, which records similar information on 26,668 individuals over the period 1972-94. Section II obtains a regression-adjusted measure of the well-being in a particular year and country - the level not explained by an individual's personal characteristics. This unexplained or residual macroeconomic well-being measure is the paper's focus.

Using a panel analysis of nations, we show that reported well-being is strongly correlated with inflation and unemployment. It is should be emphasised that we do not ask people whether they dislike inflation and unemployment. Instead individuals are asked in surveys how happy they are with life, and we show that -- possibly unknown to them -- their en masse answers move systematically with their nation's level of joblessness and rate of price change. ${ }^{5}$ The data seem to trace out an economy's wellbeing function. Section III concludes.

\section{Happiness Data}

\footnotetext{
${ }^{5}$ Our analysis complements the survey approach of, for example, Shiller (1996) who uses questions regarding inflation.
} 
In the Euro-Barometer Survey Series, a cross-section sample of Europeans are interviewed each year. One question asks "Taking all things together, how would you say things are these days--would you say you're very happy, fairly happy, or not too happy these days?". Another elicits answers to a "life satisfaction" question. This, included in part because the word happy translates imprecisely across languages, is worded, "On the whole, are you very satisfied, fairly satisfied, not very satisfied or not at all satisfied with the life you lead?". We concentrate on the life satisfaction data because they are available for a longer period of time - from 1975 to 1991 instead of just 1975-86. Unsurprisingly, happiness and life satisfaction are correlated (the correlation coefficient is 0.56 for the available period 1975-86), so the focus on life satisfaction may be sufficient. The working-paper version of this paper, available on request, presents extra results using happiness statistics.

We also study happiness data from the United States General Social Survey (1972-1994). There the happiness question reads "Taken all together, how would you say things are these days -- would you say that you are very happy, pretty happy, or not too happy?". The question was asked in each of 23 years. There is no life-satisfaction question for the U.S. It would be ideal if the well-being question's wordings were identical in the European and US cases, but they are not. However, most of the paper's conclusions rest upon cross-Europe results, where the wording of questions is the same.

We study well-being regressions for both Europe and the US. These are similar to the early micro-econometric happiness regressions for the US and the UK presented in David Blanchflower et al (1993) (Inglehart (1990) also documents the patterns in the 
micro data, mainly by looking at cross-tabulations). Although coefficients do not have a cardinal interpretation, the following personal characteristics are positively associated with reported well-being, and are statistically significant, in both continents: being employed, female, young or old (not middle aged), educated, married (neither divorced, not separated nor a widow), with few children, or belonging to a high-income quartile. Separate happiness regressions for each of the European countries largely repeat these results. For example, being unemployed is associated with much lower reported happiness levels in every European country.

Table A1 in the appendix presents a micro-econometric life satisfaction regression for Europe. Greater family income increases the likelihood that a respondent reports a high level of well-being. This effect of income is monotonic and is reminiscent of the utility function of standard economics. The regression evidence is also consistent with the common-sense idea that unemployment is a major economic source of human distress (on psychiatric stress data see Andrew Clark and Oswald (1997)). Our working paper reports further patterns from micro well-being regressions.

\section{The Inflation-Unemployment Trade-Off in Happiness Equations}

We study a basic regression of the form

$$
\text { LIFE SATISFACTION }_{i t}=\alpha \text { INFLATION }_{i t}+\beta \text { UNEMPLOYMENT }_{i t}+\varepsilon_{i}+\delta_{t}+\mu_{i t}
$$

where LIFE SATISFACTION is the average life satisfaction in country $i$ in year $t$ that is not explained by personal characteristics, UNEMPLOYMENT is the unemployment rate in country $i$ in year $t, I N F L A T I O N$ is the rate of change of consumer prices in country $i$ 
and year $t, \varepsilon_{i}$ is a country fixed effect, $\delta_{t}$ is a time effect (a year fixed effect), and $\mu_{i t}$ is an error term. Later regressions include a country-specific time trend.

A two-step methodology is employed. In the first stage, micro-econometric OLS life satisfaction regressions are estimated for each country in the sample. ${ }^{6}$ The mean residual life-satisfaction is then calculated for each nation in each year, which gives approximately 150 observations (ten countries times fifteen years) in a second-stage regression. These country-by-year unexplained life-satisfaction components are the dependent variable in a second-stage regression of the form given in the equation above. Three-year moving averages of the explanatory variables are used. This smooths out some of the noise evident in the data (and, we found, produces succinct estimating equations while leaving the substantive conclusions unaffected when compared to equations with many lagged and autoregressive terms).

For three reasons, issues of simultaneity are ignored. First, it might be believed that 'happiness' does not mold the levels of inflation and unemployment. Second, the aim is the simple one of documenting correlations in the data. Third, it is unclear what variable could serve as an instrument. Nevertheless, future research may have to return to this issue.

${ }^{6}$ Using residuals from the probit regressions introduces issues that have not been resolved in the statistical literature. The use of OLS regressions has the well-known problem that the data imply the distance between the categories very satisfied and fairly satisfied is the same as the distance between the categories fairly satisfied and not very satisfied. Experiments suggested to us that the precise cardinalization assumed did not alter the results (e.g. a binary representation of well-being led to similar equations). 


\section{Data Definitions}

LIFE SATISFACTION: The average of the residuals from a Life Satisfaction Ordinary Least Squares regression on personal characteristics. The residuals are averaged for each country and year in the sample (Mean=-0.010; Standard deviation=0.078).

UNEMPLOYMENT: The unemployment rate (three year moving average) from the OECD Economic Outlook (1995) (Mean=0.087; Standard deviation=0.037).

INFLATION: The inflation rate (three year moving average), as measured by the rate of change in consumer prices, from IMF World Tables (1994) (Mean=0.086; Standard deviation $=0.059$ ).

Results

Regression (1) of Table 1 studies the dependence of life satisfaction on the unemployment rate and the rate of inflation. The specification includes time and country dummies. The coefficients from regression (1) in Table I imply that higher unemployment and higher inflation both decrease life satisfaction. These effects, with coefficients of -2.0 and -1.2 , are each significantly different from zero at the $1 \%$ level. The implicit utility-constant trade-off between these variables is therefore approximately 1.7. In order to have a meaningful discussion about a trade-off we must make implicit assumptions, such as that, over the relevant range, utility is linear (so the margin is equal to the average). It is not possible to give a cardinal answer to the question "how much does well-being rise as inflation and unemployment decline?'.

It is necessary to make clear within a natural rate framework what such correlations mean. The estimation may be best thought of as describing preferences. Standard economic models suggest that there is no downward-sloping Phillips Curve, 
except in the short run, so knowledge of the iso-utility contours are of use to policymakers primarily in informing choice of an optimal dis-inflationary path. The estimates described above, and more broadly this kind of methodology, may be of value to central bankers concerned with the choice of policy trajectories.

Regression (2) in Table I shows that both unemployment and inflation continue to enter negatively and significantly once we introduce country-specific time trends (as requested by a referee). The coefficients on the two variables are now more similar (equality of the coefficients, in regression 2, cannot be rejected statistically at normal confidence levels). Hence life satisfaction appears to be reasonably well-approximated by a simple linear misery function defined on the sum of inflation and unemployment, $\mathrm{W}=\mathrm{W}(\pi+\mathrm{U})$.

Regressions (3) and (4) in Table I divide the sample into two time periods: before 1984 and after 1983. The coefficients keep their signs, although, as is to be expected, they are not now as well-defined. Degrees of freedom here are a source of potential concern; but this approach is primarily designed as a check on robustness. Column (5) adds into the equation a squared term in inflation - to test if inflation is particularly bad at high levels - but this leaves the key result unaffected. If an additional squared term in unemployment is entered, its effect is negligible.

Table II presents some further tests of the relationship between inflation, unemployment and well-being. Regression (6) in Table II controls for a lagged dependent variable. It shows that there is a little autoregression, but that life satisfaction data continue to be strongly correlated with macroeconomic variables. 
Regression (7) tests whether well-being depends on changes in the two macroeconomic variables. We use the growth in inflation (or unemployment) from one year to the next. There is some evidence that these changes matter. Both enter with the expected negative sign. Regression (8) in Table II shows that the inclusion of a lagged dependent variable reinforces these findings. But the underlying ideas remain the same.

It could be argued that the above calculations underestimate the cost of unemployment. The reason is that the first-stage regressions have already controlled for the personal cost of being unemployed. There is a simple way to take account of the first-stage cost of joblessness. We can calculate from regression (1) that an increase in the unemployment rate from 0 to $1 \%$ would have a cost equal to approximately 0.02 for the average citizen whether employed or unemployed. This number may be viewed as capturing a 'fear of unemployment' effect. On the other hand, from microeconomic data, a person falling unemployed experiences an actual loss equal to 0.33 in the same units. This number comes from the coefficient on being unemployed in a life-satisfaction micro regression, like the one in appendix Table A1, estimated with OLS to keep the units consistent. The average cost of a $1 \%$ point increase in the unemployment rate is therefore the sum of two components: $0.0033+0.02=0.0233$. According to the estimates, that wellbeing cost equals the loss brought about by a $1.97 \%$ inflation rate.

\section{Inflation, Unemployment and Happiness in the United States}

Since there is no question on life satisfaction in the United States General Social Survey (1972-1994), it was not possible to include the US in the panel regressions. Using GSS happiness data we estimated an OLS happiness regression - available upon request - on personal characteristics for the U.S. and obtained the mean residuals for each year. The 
year-to-year changes in the "happiness residuals" were negatively correlated with the corresponding year-to-year changes in the so-called misery index. When viewed as two individual explanatory variables, the yearly changes in happiness were somewhat more strongly associated with changes in the unemployment rate than inflation. Necessarily, the US findings stem from a single time-series regression. Broadly, the US results were approximately consistent with, though a little less well-defined than, the European results

\section{Conclusions}

The paper presents a new approach to study standard questions in macroeconomics. It studies reported well-being data on a quarter of a million people across twelve European countries and the United States. We show that people appear to be happier when inflation and unemployment are low. Consistent with the standard macroeconomics textbook's assumption that there exists a social objective function $\mathrm{W}(\pi$, $\mathrm{U})$, randomly sampled individuals mark systematically lower in well-being surveys when there is inflation or unemployment in their country. The rates of price change and joblessness affect reported satisfaction with life after controlling for the personal characteristics of the respondents, country fixed effects, year effects, country-specific time trends, and a lagged dependent variable. A function reminiscent of the textbook $\mathrm{W}(\pi, \mathrm{U})$ exists in the data.

A large literature in economics has tried to measure the losses from inflation. By examining the appropriate area under a money demand curve, Martin Bailey (1956) and 
Milton Friedman (1969) originally concluded that inflation has only small costs. Similarly, Fischer (1981) and Robert Lucas (1981) find the cost of inflation to be low, at 0.3 per cent and 0.45 per cent of national income, respectively, for a 10 per cent level of inflation. The numbers implied by our happiness-equation estimates are consistent with larger welfare losses.

At the margin, unemployment depresses reported well-being more than does inflation. In a panel that controls for country fixed-effects and year effects, the estimates suggest that people would trade off a 1 percentage point increase in the unemployment rate for a 1.7 percentage point increase in the inflation rate. Hence, according to these findings, the famous 'misery index' $\mathrm{W}(\pi+\mathrm{U})$ somewhat under-weights the unhappiness caused by unemployment.

It seems possible that the methods used in this paper -- the study of well-being regression equations -- may prove useful in other areas of macro-economics. 
Table I: Life Satisfaction Equations for Europe 1975-91

\begin{tabular}{|c|c|c|c|c|c|}
\hline & (1) & (2) & $\begin{array}{c}(3) \\
\text { Pre } 84\end{array}$ & $\begin{array}{c}(4) \\
\text { Post } 83 \\
\end{array}$ & (5) \\
\hline Unemployment t & $\begin{array}{l}-2.0 \\
(0.5)\end{array}$ & $\begin{array}{c}-1.4 \\
(0.5)\end{array}$ & $\begin{array}{l}-1.4 \\
(1.3)\end{array}$ & $\begin{array}{l}-1.8 \\
(1.2)\end{array}$ & $\begin{array}{l}-1.4 \\
(0.5)\end{array}$ \\
\hline Inflation $\mathrm{t}$ & $\begin{array}{l}-1.2 \\
(0.4)\end{array}$ & $\begin{array}{l}-1.4 \\
(0.4)\end{array}$ & $\begin{array}{l}-1.2 \\
(0.6)\end{array}$ & $\begin{array}{l}-2.4 \\
(0.8)\end{array}$ & $\begin{array}{l}-1.8 \\
(0.9)\end{array}$ \\
\hline Inflation $^{2} \mathrm{t}$ & & & & & $\begin{array}{c}1.9 \\
(3.2)\end{array}$ \\
\hline Time Trends ${ }^{1}$ & No & Yes & Yes & Yes & Yes \\
\hline Country Dummies & Yes & Yes & Yes & Yes & Yes \\
\hline Year Dummies & Yes & Yes & Yes & Yes & Yes \\
\hline No. of Obs. & 150 & 150 & 75 & 75 & 150 \\
\hline Adj. $R^{2}$ & 0.13 & 0.51 & 0.61 & 0.59 & 0.51 \\
\hline
\end{tabular}

Notes: [1] Standard errors are in parentheses. Time trends are country-specific. [2] Three-year moving averages of the explanatory variables are used. 
Table II: Checks on Life Satisfaction Equations for Europe 1975-91

\begin{tabular}{l|ccc}
\hline \hline & $(6)$ & $(7)$ & $(8)$ \\
\hline Life Satisfaction t-1 & 0.2 & & 0.2 \\
& $(0.1)$ & & $(0.1)$ \\
Unemployment t & -1.3 & -1.4 & -1.4 \\
& $(0.6)$ & $(0.5)$ & $(0.6)$ \\
Inflation t & -1.0 & -1.5 & -1.2 \\
& $(0.4)$ & $(0.4)$ & $(0.4)$ \\
$\Delta$ Unemployment t & & -1.2 & -1.1 \\
\multirow{2}{*}{$\begin{array}{l}\text { Inflation t } \\
\text { Time Trends }\end{array}$} & & $(0.7)$ & $(0.7)$ \\
Country Dummies & & -0.7 & -1.0 \\
Year Dummies & & $(0.4)$ & $(0.4)$ \\
\hline No. of Obs. & & & \\
Adj. ${ }^{2}$ & & & Yes \\
\hline \hline
\end{tabular}

Notes: [1] Standard errors are in parentheses. Time trends are country-specific. [2] Three-year moving averages of the explanatory variables are used. 


\section{Appendix}

Table A1: Life Satisfaction Micro-Equation for Europe (Ordered Probit) 1975-91.

\begin{tabular}{|c|c|c|c|}
\hline \multicolumn{2}{|l|}{ Dep Var: Reported Life Satisfaction } & Coefficient & Standard Error \\
\hline \multicolumn{2}{|l|}{ Unemployed } & -46.8 & 1.0 \\
\hline \multicolumn{2}{|l|}{ Self employed } & 6.1 & 0.8 \\
\hline \multicolumn{2}{|l|}{ Male } & -6.7 & 0.5 \\
\hline \multicolumn{2}{|l|}{ Age } & -2.8 & 0.1 \\
\hline \multicolumn{2}{|l|}{ Age Squared } & $3.18 \mathrm{e}-4$ & $9.26 \mathrm{e}-6$ \\
\hline \multicolumn{2}{|l|}{ Education to age: $15-18$ years } & 4.8 & 0.6 \\
\hline \multicolumn{2}{|l|}{$\geq 19$ years } & 9.0 & 0.7 \\
\hline & 12.9 & 0.7 \\
\hline \multicolumn{2}{|l|}{$\begin{array}{l}\text { Marital Status: Married } \\
\text { Divorced }\end{array}$} & -27.4 & 1.5 \\
\hline \multicolumn{2}{|l|}{ Separated } & -33.8 & 2.2 \\
\hline \multicolumn{2}{|l|}{ Widowed } & -15.7 & 1.1 \\
\hline \multirow[t]{3}{*}{ Num. of children between $8 \& 15 \mathrm{yrs}$ : } & 1 & -3.2 & 0.6 \\
\hline & 2 & -4.5 & 0.8 \\
\hline & 3 & -9.7 & 1.2 \\
\hline & 16.8 & 0.7 \\
\hline \multicolumn{2}{|l|}{$\begin{array}{c}\text { Income Quartiles : Second } \\
\text { Third }\end{array}$} & 30.2 & 0.7 \\
\hline \multicolumn{2}{|l|}{ Fourth (highest) } & 45.8 & 0.7 \\
\hline \multicolumn{2}{|l|}{ Retired } & 7.9 & 0.9 \\
\hline \multicolumn{2}{|l|}{ In school } & 5.8 & 1.1 \\
\hline \multicolumn{2}{|l|}{ At home } & 4.8 & 0.7 \\
\hline
\end{tabular}

Notes: [1] Number of Observations $=264,710$. Log-likelihood $=269677 . \mathrm{Chi}^{2}(47)=49196$. Cut 1=1.648, Cut2 $=-0.776$, Cut $3=0.893$. [2] The regression includes country and year dummies from 1975 to 1991 . The country dummies (standard errors) are: Belgium $0.494(0.010)$, Netherlands 0.880 (0.010), Germany 0.358 (0.009), Italy -0.118 (0.009), Luxembourg $0.753(0.014)$, Denmark 1.180 (0.010), Ireland 0.577 (0.010), Britain 0.520 (0.010), Portugal -0.260 (0.012), Greece $0.175(0.010)$ and Spain $0.197(0.013)$. The base country is France. [3] The exact question is: "On the whole, are you very satisfied, fairly satisfied, not very satisfied, or not at all satisfied with the life you lead?". 


\section{References}

Bailey, Martin (1956). "The Welfare Cost of Inflationary Finance". Journal of Political Economy, 64, 64-93.

Barro, Robert J. and Gordon, David (1983). "A Positive Theory of Monetary Policy in a Natural Rate Model", Journal of Political Economy, 91, 589-610.

Blanchard, Olivier and Fischer, Stanley (1989). Lectures on Macroeconomics, MIT Press, Cambridge.

Blanchflower, David, Oswald, Andrew J. and Warr, Peter B. (1993). "Well-being Over Time in Britain and the USA", London School of Economics, Mimeo.

Burda, Michael and Wyplosz, Charles (1993). Macroeconomics: A European Text, Oxford University Press, Oxford and New York.

Clark, Andrew and Oswald, Andrew J. (1994). "Unhappiness and Unemployment", Economic Journal, September, 104, 648-659.

Diener, Edward (1984). "Subjective Well-Being", Psychological Bulletin, 93, 542-575.

Easterlin, Richard (1974). "Does Economic Growth Improve the Human Lot? Some Empirical Evidence". In Nations and Households in Economic Growth: Essays in Honour of Moses Abramovitz, (ed. P. A. David and M. W. Reder). New York and London: Academic Press.

Fischer, Stanley (1981). "Towards an Understanding of the Costs of Inflation: II, Carnegie-Rochester Conference Series on Public Policy, 15, 5-41.

Frank, Robert H. (1985). Choosing the Right Pond, Oxford University Press, New York and Oxford.

Friedman, Milton (1969). "The Optimum Quantity of Money", The Optimum Quantity of Money and Other Essays, Aldine, Chicago.

Hall, Robert E. and Taylor, John. (1997). Macroeconomics, $5^{\text {th }}$ edition, Norton Press, New York.

Inglehart, Ronald (1990). Culture Shift in Advanced Industrial Society, Princeton University Press, Princeton.

Kahneman, Daniel, Wakker, Peter P. and Sarin, Rakesh (1997). "Back to Bentham? Explorations of Experienced Utility", Quarterly Journal of Economics, 112, 375406.

Lucas, Robert E., Jr. (1981). "Discussion of: Stanley Fischer, 'Towards an Understanding of the Costs of Inflation: II", Carnegie-Rochester Conference Series on Public Policy, 15, 43-52.

Mankiw, N. Gregory (1997). Macroeconomics (3rd Edition), Worth Publishers, New York.

Morawetz, David et al (1977). "Income Distribution and Self-Rated Happiness: Some Empirical Evidence", Economic Journal, 87, 511-22.

Myers, David (1993) The Pursuit of Happiness, Aquarian, London.

$\mathrm{Ng}$, Yew-Kwang (1996). "Happiness Surveys: Some Comparability Issues and an Exploratory Survey Based on Just Perceivable Increments", Social Indicators Research, 38, 1-27

$\mathrm{Ng}$, Yew-Kwang. (1997). "A Case for Happiness, Cardinalism, and Interpersonal Comparability", Economic Journal, September, 107, 1848-1858.

Oswald, Andrew J. (1997). "Happiness and Economic Performance", Economic Journal, September, 107, 1815-1831 .

Pavot, William (1991) et al. "Further Validation of the Satisfaction with Life Scale: Evidence for the Cross-Method Convergence of Well-Being Measures", Journal of Personality Assessment, 57, 149-161.

Shiller, Robert (1996). "Why Do People Dislike Inflation?", National Bureau of Economic Research Working Paper, \#5539. 
2008

B01-08

2007

B03-07

B02-07

B01-07

\section{6}

B03-06

B02-06

B01-06

2005

B11-05

B10-05

B09-05

B08-05

B07-05

B06-05

B05-05

B04-05

B03-05

B02-05

B01-05

2004

B33-04

B32-04

B31-04

B30-04

B29-04

B28-04

B27-04

B26-04

B25-04

B24-04

B23-04

B22-04

B21-04

B20-04

B19-04
Euro-Diplomatie durch gemeinsame „Wirtschaftsregierung“

Löhne und Steuern im Systemwettbewerb der Mitgliedstaaten der Europäischen Union

Konsolidierung und Reform der Europäischen Union

The Ratification of European Treaties - Legal and Constitutional Basis of a European Referendum.

Financial Frictions, Capital Reallocation, and Aggregate Fluctuations

Financial Openness and Macroeconomic Volatility

A Welfare Analysis of Capital Account Liberalization

Das Kompetenz- und Entscheidungssystem des Vertrages von Rom im Wandel seiner Funktion und Verfassung

Die Schutzklauseln der Beitrittsverträge

Measuring Tax Burdens in Europe

Remittances as Investment in the Absence of Altruism

Economic Integration in a Multicone World?

Banking Sector (Under?)Development in Central and Eastern Europe

Regulatory Standards Can Lead to Predation

Währungspolitik als Sozialpolitik

Public Education in an Integrated Europe: Studying to Migrate and Teaching to Stay?

Voice of the Diaspora: An Analysis of Migrant Voting Behavior Macroeconomic Adjustment in the New EU Member States

The Effects of Transition and Political Instability On Foreign Direct Investment Inflows: Central Europe and the Balkans The Choice of Exchange Rate Regimes in Developing Countries: A Mulitnominal Panal Analysis

Fear of Floating and Fear of Pegging: An Empirical Anaysis of De Facto Exchange Rate Regimes in Developing Countries

Der Vollzug von Gemeinschaftsrecht über die Mitgliedstaaten und seine Rolle für die EU und den Beitrittsprozess

Deutschlands Wirtschaft, seine Schulden und die Unzulänglichkeiten der einheitlichen Geldpolitik im Eurosystem

Fiscal Crises in U.S. Cities: Structural and Non-structural Causes

Firm Performance and Privatization in Ukraine

Analyzing Trade Opening in Ukraine: Effects of a Customs Union with the EU

Exchange Rate Risk and Convergence to the Euro

The Endogeneity of Money and the Eurosystem

Which Lender of Last Resort for the Eurosystem?

Non-Discretonary Monetary Policy: The Answer for Transition Economies?

The Effectiveness of Subsidies Revisited: Accounting for Wage and Employment Effects in Business R+D

Money Market Pressure and the Determinants of Banking Crises

Die Stellung der Europäischen Zentralbank nach dem Verfassungsvertrag
Martin Seidel

Martin Seidel

Martin Seidel

Martin Seidel

Jürgen von Hagen, Haiping Zhang

Jürgen von Hagen, Haiping Zhang

Jürgen von Hagen, Haiping Zhang

Martin Seidel

Martin Seidel

Guntram B. Wolff

Gabriel González-König

Christian Volpe Martincus, Jennifer Pédussel Wu

Jürgen von Hagen, Valeriya Dinger

Stefan Lutz

Martin Seidel

Panu Poutvaara

Jan Fidrmuc, Orla Doyle

Jürgen von Hagen, Iulia Traistaru

Josef C. Brada, Ali M. Kutan, Taner M. Yigit

Jürgen von Hagen, Jizhong Zhou

Jürgen von Hagen, Jizhong Zhou

Martin Seidel

Dieter Spethmann, Otto Steiger

Guntram B. Wolff

Galyna Grygorenko, Stefan Lutz Oksana Harbuzyuk, Stefan Lutz

Lucjan T. Orlowski

Otto Steiger

Otto Steiger

Elham-Mafi Kreft, Steven F. Kreft

Volker Reinthaler, Guntram B. Wolff

Jürgen von Hagen, Tai-kuang Ho

Martin Seidel 
B18-04

B17-04

B16-04

B15-04

B14-04

B13-04

B12-04

B11-04

B10-04

B09-04

B08-04

B07-04

B06-04

B05-04

B04-04

B03-04

B02-04

B01-04

2003

B29-03

B28-03

B27-03

B26-03

B25-03

B24-03

B23-03

B22-03

B21-03

B20-03

B19-03
Transmission Channels of Business Cycles Synchronization in an Enlarged EMU

Foreign Exchange Regime, the Real Exchange Rate and Current Account Sustainability: The Case of Turkey

Does It Matter Where Immigrants Work? Traded Goods, Nontraded Goods, and Sector Specific Employment

Do Economic Integration and Fiscal Competition Help to Explain Local Patterns?

Euro Adoption and Maastricht Criteria: Rules or Discretion? The Role of Electoral and Party Systems in the Development of Fiscal Institutions in the Central and Eastern European Countries

Measuring and Explaining Levels of Regional Economic Integration

Economic Integration and Location of Manufacturing Activities: Evidence from MERCOSUR

Economic Integration and Industry Location in Transition Countries

Testing Creditor Moral Hazard in Souvereign Bond Markets: A Unified Theoretical Approach and Empirical Evidence

European Integration, Productivity Growth and Real Convergence

The Contribution of Income, Social Capital, and Institutions to Human Well-being in Africa

Rural Urban Inequality in Africa: A Panel Study of the Effects of Trade Liberalization and Financial Deepening

Money Rules for the Eurozone Candidate Countries

Who is in Favor of Enlargement? Determinants of Support for EU Membership in the Candidate Countries' Referenda

Over- and Underbidding in Central Bank Open Market Operations Conducted as Fixed Rate Tender

Total Factor Productivity and Economic Freedom Implications for EU Enlargement

Die neuen Schutzklauseln der Artikel 38 und 39 des Beitrittsvertrages: Schutz der alten Mitgliedstaaten vor Störungen durch die neuen Mitgliedstaaten

Macroeconomic Implications of Low Inflation in the Euro Area The Effects of Transition and Political Instability on Foreign Direct Investment: Central Europe and the Balkans

The Performance of the Euribor Futures Market: Efficiency and the Impact of ECB Policy Announcements (Electronic Version of International Finance)

Souvereign Risk Premia in the European Government Bond Market (überarbeitete Version zum Herunterladen)

How Flexible are Wages in EU Accession Countries?

Monetary Policy Reaction Functions: ECB versus Bundesbank Economic Integration and Manufacturing Concentration Patterns: Evidence from Mercosur

Reformzwänge innerhalb der EU angesichts der Osterweiterung Reputation Flows: Contractual Disputes and the Channels for Inter-Firm Communication

Urban Primacy, Gigantism, and International Trade: Evidence from Asia and the Americas

An Empirical Analysis of Competing Explanations of Urban Primacy Evidence from Asia and the Americas
Iulia Traistaru

Sübidey Togan, Hasan Ersel

Harry P. Bowen, Jennifer Pédussel Wu

Christian Volpe Martincus

Jiri Jonas

Sami Yläoutinen

Jennifer Pédussel Wu

Pablo Sanguinetti, lulia Traistaru, Christian Volpe Martincus

Laura Resmini

Ayse Y. Evrensel, Ali M. Kutan

Taner M. Yigit, Ali M. Kutan

Mina Baliamoune-Lutz, Stefan $H$. Lutz

Mina Baliamoune-Lutz, Stefan H. Lutz

Lucjan T. Orlowski

Orla Doyle, Jan Fidrmuc

Ulrich Bindseil

Ronald L. Moomaw, Euy Seok Yang

Martin Seidel

Jürgen von Hagen, Boris Hofmann Josef C. Brada, Ali M. Kutan, Taner $M$. Yigit

Kerstin Bernoth, Juergen von Hagen

Kerstin Bernoth, Juergen von Hagen, Ludger Schulknecht

Anna lara, Iulia Traistaru

Bernd Hayo, Boris Hofmann

Iulia Traistaru, Christian Volpe

Martincus

Martin Seidel

William Pyle

Ronald L. Moomaw, Mohammed A. Alwosabi

Ronald L. Moomaw, Mohammed

A. Alwosabi 
B18-03 The Effects of Regional and Industry-Wide FDI Spillovers on Export of Ukrainian Firms

B17-03 Determinants of Inter-Regional Migration in the Baltic States B16-03 South-East Europe: Economic Performance, Perspectives, and Policy Challenges

B15-03 Employed and Unemployed Search: The Marginal Willingness to Pay for Attributes in Lithuania, the US and the Netherlands

B14-03 FCls and Economic Activity: Some International Evidence

B13-03 The IS Curve and the Transmission of Monetary Policy: Is there a Puzzle?

B12-03 What Makes Regions in Eastern Europe Catching Up? The Role of Foreign Investment, Human Resources, and Geography

B11-03 Die Weisungs- und Herrschaftsmacht der Europäischen Zentralbank im europäischen System der Zentralbanken - eine rechtliche Analyse

B10-03 Foreign Direct Investment and Perceptions of Vulnerability to Foreign Exchange Crises: Evidence from Transition Economies

B09-03 The European Central Bank and the Eurosystem: An Analysis of the Missing Central Monetary Institution in European Monetary Union

B08-03 The Determination of Capital Controls: Which Role Do Exchange Rate Regimes Play?

B07-03 Nach Nizza und Stockholm: Stand des Binnenmarktes und Prioritäten für die Zukunft

B06-03 Fiscal Discipline and Growth in Euroland. Experiences with the Stability and Growth Pact

B05-03 Reconsidering the Evidence: Are Eurozone Business Cycles Converging?

B04-03 Do Ukrainian Firms Benefit from FDI?

B03-03 Europäische Steuerkoordination und die Schweiz

B02-03 Commuting in the Baltic States: Patterns, Determinants, and Gains

B01-03 Die Wirtschafts- und Währungsunion im rechtlichen und politischen Gefüge der Europäischen Union

2002

B30-02

B29B-02 Trade Agreements as Self-protection

B29A-02 Growth and Business Cycles with Imperfect Credit Markets

B28-02 Inequality, Politics and Economic Growth

B27-02 Poverty Traps and Growth in a Model of Endogenous Time Preference

B26-02 Monetary Convergence and Risk Premiums in the EU Candidate Countries

B25-02 Trade Policy: Institutional Vs. Economic Factors

B24-02 The Effects of Quotas on Vertical Intra-industry Trade

B23-02 Legal Aspects of European Economic and Monetary Union

B22-02 Der Staat als Lender of Last Resort - oder: Die Achillesverse des Eurosystems

B21-02 Nominal and Real Stochastic Convergence Within the Transition Economies and to the European Union: Evidence from Panel Data

B20-02 The Impact of News, Oil Prices, and International Spillovers on Russian Fincancial Markets
Stefan H. Lutz, Oleksandr Talavera, Sang-Min Park

Mihails Hazans

lulia Traistaru, Jürgen von Hagen

Jos van Ommeren, Mihails Hazans

Charles Goodhart, Boris Hofmann

Charles Goodhart, Boris Hofmann

Gabriele Tondl, Goran Vuksic

Martin Seidel

Josef C. Brada, Vladimír Tomsík

Gunnar Heinsohn, Otto Steiger

Jürgen von Hagen, Jizhong Zhou

Martin Seidel

Jürgen von Hagen

Michael Massmann, James Mitchell

Stefan H. Lutz, Oleksandr Talavera

Stefan H. Lutz

Mihails Hazans

Martin Seidel

Marcus Hagedorn, Ashok Kaul, Tim Mennel Jennifer Pédussel Wu

Debajyoti Chakrabarty

Debajyoti Chakrabarty

Debajyoti Chakrabarty

Lucjan T. Orlowski

Stefan Lutz

Stefan Lutz

Martin Seidel

Otto Steiger

Ali M. Kutan, Taner M. Yigit

Bernd Hayo, Ali M. Kutan 
East Germany: Transition with Unification, Experiments and Experiences

B18-02 Regional Specialization and Employment Dynamics in Transition Countries

B17-02 Specialization and Growth Patterns in Border Regions of Accession Countries

B16-02 Regional Specialization and Concentration of Industrial Activity in Accession Countries

B15-02 Does Broad Money Matter for Interest Rate Policy?

B14-02 The Long and Short of It: Global Liberalization, Poverty and Inequality

B13-02 De Facto and Official Exchange Rate Regimes in Transition Economies

B12-02 Argentina: The Anatomy of A Crisis

B11-02 The Eurosystem and the Art of Central Banking

B10-02

B09-02

B08-02

B07-02

B06-02

B05-02

B04-02

B03-02

B02-02

B01-02

2001

B29-01

B28-01

B27-01

B26-01

B25-01

B24-01

B23-01

B22-01

B21-01

B20-01

B19-01
National Origins of European Law: Towards an Autonomous System of European Law?

Monetary Policy in the Euro Area - Lessons from the First Years Has the Link Between the Spot and Forward Exchange Rates Broken Down? Evidence From Rolling Cointegration Tests

Perspektiven der Erweiterung der Europäischen Union

Is There Asymmetry in Forward Exchange Rate Bias? MultiCountry Evidence

Real and Monetary Convergence Within the European Union and Between the European Union and Candidate Countries: A Rolling Cointegration Approach

\section{Asymmetric Monetary Policy Effects in EMU}

The Choice of Exchange Rate Regimes: An Empirical Analysis for Transition Economies

The Euro System and the Federal Reserve System Compared: Facts and Challenges

Does Inflation Targeting Matter?

Is Kazakhstan Vulnerable to the Dutch Disease?

Political Economy of the Nice Treaty: Rebalancing the EU Council. The Future of European Agricultural Policies

Investor Panic, IMF Actions, and Emerging Stock Market Returns and Volatility: A Panel Investigation

Regional Effects of Terrorism on Tourism: Evidence from Three Mediterranean Countries

Monetary Convergence of the EU Candidates to the Euro: A Theoretical Framework and Policy Implications

Disintegration and Trade

Migration and Adjustment to Shocks in Transition Economies Strategic Delegation and International Capital Taxation

Balkan and Mediterranean Candidates for European Union Membership: The Convergence of Their Monetary Policy With That of the Europaen Central Bank

An Empirical Inquiry of the Efficiency of Intergovernmental Transfers for Water Projects Based on the WRDA Data

Detrending and the Money-Output Link: International Evidence
Jürgen von Hagen, Rolf $R$ Strauch, Guntram B. Wolff

Iulia Traistaru, Guntram B. Wolff

Laura Resmini

Iulia Traistaru, Peter Nijkamp, Simonetta Longhi

Matthias Brückner, Andreas Schaber

Christian E. Weller, Adam Hersch

Jürgen von Hagen, Jizhong Zhou

Jiri Jonas

Gunnar Heinsohn, Otto Steiger

Martin Seidel

Volker Clausen, Bernd Hayo

Ali M. Kutan, Su Zhou

Martin Seidel

Su Zhou, Ali M. Kutan

Josef C. Brada, Ali M. Kutan, Su

Zhou

Volker Clausen, Bernd Hayo

Jürgen von Hagen, Jizhong Zhou

Karlheinz Ruckriegel, Franz Seitz

Manfred J. M. Neumann, Jürgen von Hagen

Karlygash Kuralbayeva, Ali M. Kutan, Michael L. Wyzan

Deutsch-Französisches Wirt-

schaftspolitisches Forum

Bernd Hayo, Ali M. Kutan

Konstantinos Drakos, Ali M. Ku$\tan$

Lucjan T. Orlowski

Jarko and Jan Fidrmuc

Jan Fidrmuc

Matthias Brückner

Josef C. Brada, Ali M. Kutan

Anna Rubinchik-Pessach

R.W. Hafer, Ali M. Kutan 
B18-01 Monetary Policy in Unknown Territory. The European Central Bank in the Early Years

B17-01 Executive Authority, the Personal Vote, and Budget Discipline in Latin American and Carribean Countries

B16-01 Sources of Inflation and Output Fluctuations in Poland and Hungary: Implications for Full Membership in the European Union

B15-01 Programs Without Alternative: Public Pensions in the OECD

B14-01 Formal Fiscal Restraints and Budget Processes As Solutions to a Deficit and Spending Bias in Public Finances - U.S. Experience and Possible Lessons for EMU

B13-01 German Public Finances: Recent Experiences and Future Challenges

B12-01 The Impact of Eastern Enlargement On EU-Labour Markets. Pensions Reform Between Economic and Political Problems

B11-01 Inflationary Performance in a Monetary Union With Large Wage Setters

B10-01 Integration of the Baltic States into the EU and Institutions of Fiscal Convergence: A Critical Evaluation of Key Issues and Empirical Evidence

B09-01 Democracy in Transition Economies: Grease or Sand in the Wheels of Growth?

B08-01 The Functioning of Economic Policy Coordination

B07-01 The Convergence of Monetary Policy Between Candidate Countries and the European Union

B06-01 Opposites Attract: The Case of Greek and Turkish Financial Markets

B05-01 Trade Rules and Global Governance: A Long Term Agenda. The Future of Banking.

B04-01 The Determination of Unemployment Benefits

B03-01 Preferences Over Inflation and Unemployment: Evidence from Surveys of Happiness

B02-01 The Konstanz Seminar on Monetary Theory and Policy at Thirty

B01-01 Divided Boards: Partisanship Through Delegated Monetary Policy

\section{0}

B20-00

B19-00

B18-00

B17-00

B16-00

B15-00

Breakin-up a Nation, From the Inside

Income Dynamics and Stability in the Transition Process, general Reflections applied to the Czech Republic

Budget Processes: Theory and Experimental Evidence

Rückführung der Landwirtschaftspolitik in die Verantwortung der Mitgliedsstaaten? - Rechts- und Verfassungsfragen des Gemeinschaftsrechts

The European Central Bank: Independence and Accountability

B14-00

Regional Risk Sharing and Redistribution in the German Federation

$\begin{array}{ll} & \text { nomies: The Case of Poland and Hungary } \\ \text { B13-00 Back to the Future: The Growth Prospects of Transition Eco- }\end{array}$

Sources of Real Exchange Rate Fluctuations in Transition Economies: The Case of Poland and Hungary nomies Reconsidered
Jürgen von Hagen, Matthias Brückner

Mark Hallerberg, Patrick Marier

Selahattin Dibooglu, Ali M. Kutan

Christian E. Weller

Rolf R. Strauch, Jürgen von Hagen

Jürgen von Hagen, RolfR. Strauch

Deutsch-Französisches Wirt-

schaftspolitisches Forum

Lilia Cavallar

Ali M. Kutan, Niina Pautola-Mol

Jan Fidrmuc

Jürgen von Hagen, Susanne Mundschenk

Josef C. Brada, Ali M. Kutan

Konstantinos Drakos, Ali M. Ku$\tan$

Deutsch-Französisches Wirtschaftspolitisches Forum

Rafael di Tella, Robert J. Mac-

Culloch

Rafael di Tella, Robert J. MacCulloch, Andrew J. Oswald

Michele Fratianni, Jürgen von $\mathrm{Ha}$ gen

Etienne Farvaque, Gael Lagadec

Etienne Farvaque

Jens Hölscher

Karl-Martin Ehrhart, Roy Gardner, Jürgen von Hagen, Claudia Keser Martin Seidel

Christa Randzio-Plath, Tomasso Padoa-Schioppa

Jürgen von Hagen, Ralf Hepp

Selahattin Dibooglu, Ali M. Kutan

Nauro F. Campos 
Rechtsetzung und Rechtsangleichung als Folge der Einheitlichen Europäischen Währung

B11-00 A Dynamic Approach to Inflation Targeting in Transition Economies

B10-00 The Importance of Domestic Political Institutions: Why and How Belgium Qualified for EMU

B09-00 Rational Institutions Yield Hysteresis

B08-00 The Effectiveness of Self-Protection Policies for Safeguarding Emerging Market Economies from Crises

B07-00 Financial Supervision and Policy Coordination in The EMU

B06-00 The Demand for Money in Austria

B05-00 Liberalization, Democracy and Economic Performance during Transition

B04-00 A New Political Culture in The EU - Democratic Accountability of the ECB

B03-00 Integration, Disintegration and Trade in Europe: Evolution of Trade Relations during the 1990's

B02-00 Inflation Bias and Productivity Shocks in Transition Economies: The Case of the Czech Republic

B01-00 Monetary Union and Fiscal Federalism

\section{9}

B26-99

B25-99

B24-99

B23-99

B22-99

B21-99

B20-99

B19-99

B18-99

B17-99

B16-99

B15-99

B14-99

B13-99

B12 -99

B11-99

B10-99

B09-99

B08-99
Skills, Labour Costs, and Vertically Differentiated Industries: A General Equilibrium Analysis

Micro and Macro Determinants of Public Support for Market Reforms in Eastern Europe

\section{What Makes a Revolution?}

Informal Family Insurance and the Design of the Welfare State

Partisan Social Happiness

The End of Moderate Inflation in Three Transition Economies?

Subnational Government Bailouts in Germany

The Evolution of Monetary Policy in Transition Economies

Why are Eastern Europe's Banks not failing when everybody else's are?

Stability of Monetary Unions: Lessons from the Break-Up of Czechoslovakia

Multinational Banks and Development Finance

Financial Crises after Financial Liberalization: Exceptional Circumstances or Structural Weakness?

Industry Effects of Monetary Policy in Germany

Fiancial Fragility or What Went Right and What Could Go Wrong in Central European Banking?

Size Distortions of Tests of the Null Hypothesis of Stationarity: Evidence and Implications for Applied Work

Financial Supervision and Policy Coordination in the EMU

Financial Liberalization, Multinational Banks and Credit Supply: The Case of Poland

Monetary Policy, Parameter Uncertainty and Optimal Learning The Connection between more Multinational Banks and less Real Credit in Transition Economies
Martin Seidel

Lucjan T. Orlowski

Marc Hallerberg

Rafael Di Tella, Robert MacCulloch

Kenneth Kletzer

Deutsch-Französisches

Wirtschaftspolitisches Forum

Bernd Hayo

Jan Fidrmuc

Christa Randzio-Plath

Jarko Fidrmuc, Jan Fidrmuc

Josef C. Barda, Arthur E. King, Ali

M. Kutan

Kenneth Kletzer, Jürgen von Hagen

Stefan Lutz, Alessandro Turrini

Bernd Hayo

Robert MacCulloch

Rafael Di Tella, Robert Mac-

Culloch

Rafael Di Tella, Robert Mac-

Culloch

Josef C. Brada, Ali M. Kutan

Helmut Seitz

Ali M. Kutan, Josef C. Brada

Christian E. Weller, Bernard Morzuch

Jan Fidrmuc, Julius Horvath and Jarko Fidrmuc

Christian E.Weller and Mark J. Scher

Christian E. Weller

Bernd Hayo and Birgit Uhlenbrock Christian E. Weller and Jürgen von Hagen

Mehmet Caner and Lutz Kilian

Deutsch-Französisches Wirtschaftspolitisches Forum

Christian Weller

Volker Wieland

Christian Weller 
B07-99 Comovement and Catch-up in Productivity across Sectors: Evidence from the OECD

B06-99 Productivity Convergence and Economic Growth: A Frontier Production Function Approach

B05-99 Tumbling Giant: Germany‘s Experience with the Maastricht Fiscal Criteria

B04-99 The Finance-Investment Link in a Transition Economy: Evidence for Poland from Panel Data

B03-99 The Macroeconomics of Happiness

B02-99 The Consequences of Labour Market Flexibility: Panel Evidence Based on Survey Data

B01-99 The Excess Volatility of Foreign Exchange Rates: Statistical Puzzle or Theoretical Artifact?

1998

B16-98 Labour Market + Tax Policy in the EMU

B15-98 Can Taxing Foreign Competition Harm the Domestic Industry?

B14-98 Free Trade and Arms Races: Some Thoughts Regarding EURussian Trade

B13-98 Fiscal Policy and Intranational Risk-Sharing

B12-98 Price Stability and Monetary Policy Effectiveness when Nominal Interest Rates are Bounded at Zero

B11A-98 Die Bewertung der "dauerhaft tragbaren öffentlichen Finanzlage"der EU Mitgliedstaaten beim Übergang zur dritten Stufe der EWWU

B11-98 Exchange Rate Regimes in the Transition Economies: Case Study of the Czech Republic: 1990-1997

B10-98 Der Wettbewerb der Rechts- und politischen Systeme in der Europäischen Union

B09-98 U.S. Monetary Policy and Monetary Policy and the ESCB

B08-98 Money-Output Granger Causality Revisited: An Empirical Analysis of EU Countries (überarbeitete Version zum Herunterladen)

B07-98 Designing Voluntary Environmental Agreements in Europe: Some Lessons from the U.S. EPA's 33/50 Program

B06-98 Monetary Union, Asymmetric Productivity Shocks and Fiscal Insurance: an Analytical Discussion of Welfare Issues

B05-98 Estimating a European Demand for Money (überarbeitete Version zum Herunterladen)

B04-98 The EMU's Exchange Rate Policy

B03-98 Central Bank Policy in a More Perfect Financial System

B02-98 Trade with Low-Wage Countries and Wage Inequality

B01-98 Budgeting Institutions for Aggregate Fiscal Discipline

1997

B04-97

B-03-97

Macroeconomic Stabilization with a Common Currency: Does European Monetary Unification Create a Need for Fiscal Insurance or Federalism?

tions: Some Lessons from the US Electric Utility Industry

B02-97 Employment and EMU

B01-97 A Stability Pact for Europe
Christopher M. Cornwell and JensUwe Wächter

Christopher M. Cornwell and JensUwe Wächter

Jürgen von Hagen and Rolf

Strauch

Christian Weller

Rafael Di Tella, Robert Mac-

Culloch and Andrew J. Oswald

Rafael Di Tella and Robert MacCulloch

Robert B.H. Hauswald

Deutsch-Französisches

Wirtschaftspolitisches Forum

Stefan Lutz

Rafael Reuveny and John Maxwell

Jürgen von Hagen

Athanasios Orphanides and Volker Wieland

Rolf Strauch

Julius Horvath and Jiri Jonas

Martin Seidel

Robert L. Hetzel

Bernd Hayo

John W. Maxwell

Kenneth Kletzer

Bernd Hayo

Deutsch-Französisches Wirtschaftspolitisches Forum

Jürgen von Hagen / Ingo Fender

Jaleel Ahmad

Jürgen von Hagen

Kenneth Kletzer

Tom Lyon / John Mayo

Deutsch-Französisches Wirtschaftspolitisches Forum

(a Forum organized by ZEI) 
ISSN 1436 - 6053

Zentrum für Europäische Integrationsforschung

Center for European Integration Studies

Rheinische Friedrich-Wilhelms-Universität Bonn

Walter-Flex-Strasse 3

Tel.: +49-228-73-1732

D-53113 Bonn

Fax: +49-228-73-1809

Germany

www.zei.de 